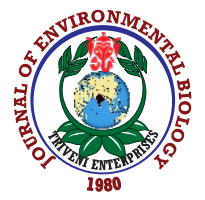

\title{
Nutritional evaluation of freshwater bivalve, Lamellidens spp. from the upper Brahmaputra basin, Assam with special reference to dietary essential amino acids, omega fatty acids and minerals
}

\author{
J. Sonowal ${ }^{*}$ and D. Kardong \\ Department of Life Sciences, Dibrugarh University, Dibrugarh-786 004, India \\ *Corresponding Author Email : jyotish194@gmail.com
}

\section{Abstract}

Aim: Lamellidens (Unionidae: Bivalvia) or Indian pond mussel is very popular as food among many natives of Assam and Northeast India. However, due to the lack of systematic studies the nutritional significance and utility of Lamellidens spp. could not be validated for human consumption. Therefore, an attempt was made to study the nutritional values of Lamellidens spp. of this region.

Methodology: Live samples were collected from the Upper Brahmaputra basin of Assam, India. Edible tissues were dissected and amino acid, fatty acid and mineral content were analyzed with HPLC Breeze 2 system, GC/GC$M S$ and ICP-AES, respectively.

Results: Based on the current investigation, Lamellidens spp. were found to be rich in protein with dietary essential amino acids and taste active amino acids viz., glutamic acid, glycine, alanine, proline and arginine. The tissues of Lamellidens spp. also contained medium-chain fatty acids, long-chain saturated fatty acids, monounsaturated fatty acids and polyunsaturated fatty acids, including high ratio
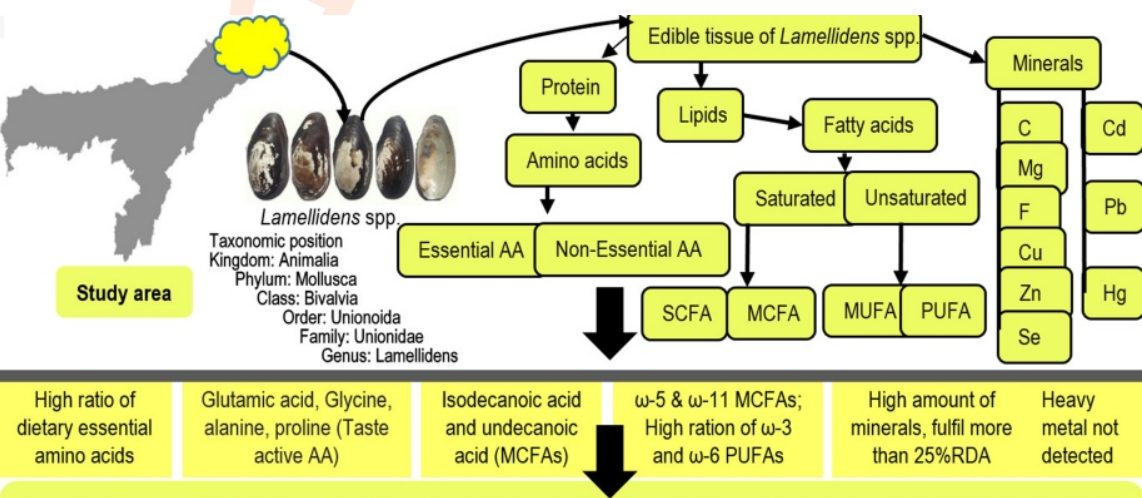

Lamellidens spp. were found to be a good source of proteins, dietary essential amino acids, fatty acids, macro and trace minerals for human nutrition. Therefore, Lamellidens spp. may be considered as an alternative meat source and a rich supplement of human nutrient which can provide health security of the rural people in the region.

of dietary essential omega-3 $(\omega-3)$ and omega- $6(\omega-6)$ fatty acids with certain variations among the species. The mineral analysis showed that Lamellidens spp. were a good source of macro and trace elements for human consumption, which can fulfil more than $25 \%$ recommended dietary allowance of minerals. No selected heavy metal was detected in the tissues of Lamellidens spp.

Interpretation: From the nutritional analysis it was evident that Lamellidens spp. were good source of protein, fatty acids and minerals as a rich supplement of human nutrition as compared to other commercial meat sources. Through the development of culture protocol, a sustainable approach could be adopted to exploit the aquatic resource to provide food security for the rural people in the region.

Key words: Bivalves, Brahmaputra basin, Lamellidens spp., Omega-3, Polyunsaturated fatty acids

How to cite : Sonowal, J. and D. Kardong: Nutritional evaluation of freshwater bivalve, Lamellidens spp. from the upper Brahmaputra basin, Assam with special reference to dietary essential amino acids, omega fatty acids and minerals. J. Environ. Biol., 41, 931-941 (2020). 


\section{Introduction}

There has been expanding worldwide interest of fundamental supplements to meet the prerequisite of increasing populace which has made huge weight on the current bio-assets on the earth. Therefore, searching for alternative and nonconventional food sources among the consumers to meet their supplemental requirement is common (Suna and Çopur, 2018). Conventionally, poultry, pork, beef, lamb and fish are considered as the major sources of animal protein for humans. According to FAO estimates, in "The State of Food Security and Nutrition in the World 2017" report, 190.7 million (14.5\%) people in India were undernourished. This prevailing situation demands inventorization of more nutritive food sources to meet the dietary requirements of increasing population. In Assam, the consumption pressure on fish has increased due to the rising human population, resulting in its shift to other animal groups notably mollusc for natural protein and other vital nutrient sources.

Freshwater molluscs are considered an ecosystem engineer (Elder and Collins, 1991; Maltchik et al., 2010) for the pivotal role it plays in the aquatic ecosystem by changing the physical state of biotic and abiotic components that control the availability of resources to other organisms (Gutierrez et al.,
2003; Lydeard et al., 2004; Budha et al., 2010). Apart from their role in the ecosystem, several species of freshwater molluscs are used by people across the globe as low cost non-conventional nutritious food. Mollusc is recognized as a species of culinary delicacies across the globe (Linehan et al., 1999; Dridi et al., 2007; Ab Lah et al., 2016). Thus, species like Pila, Bellamya, Brotia (Gastropoda), Lamellidens and Parreysia (Bivalvia) are highly popular and consumed by many tribes of NE India. Lamellidens spp. or sometimes referred to as Indian pond mussel are one of the most widely harvested freshwater bivalve species used for human consumption in Nepal and Bangladesh (Madhyastha et al., 2010). The bivalve species have been found as popular meat sources among many indigenous communities of upper Assam due to its abundance in the natural water bodies. But, research on the nutritional aspects of Lamellidens spp. from this part of the region has remained unaddressed till date. Therefore, an attempt was made to study the nutritive values of Lamellidens spp., especially in terms of amino acids, omega fatty acids and mineral contents.

\section{Materials and Methods}

Sampling: Live Lamellidens spp. were collected from 17 different sampling stations of the Upper Brahmaputra basin of Assam (Fig.

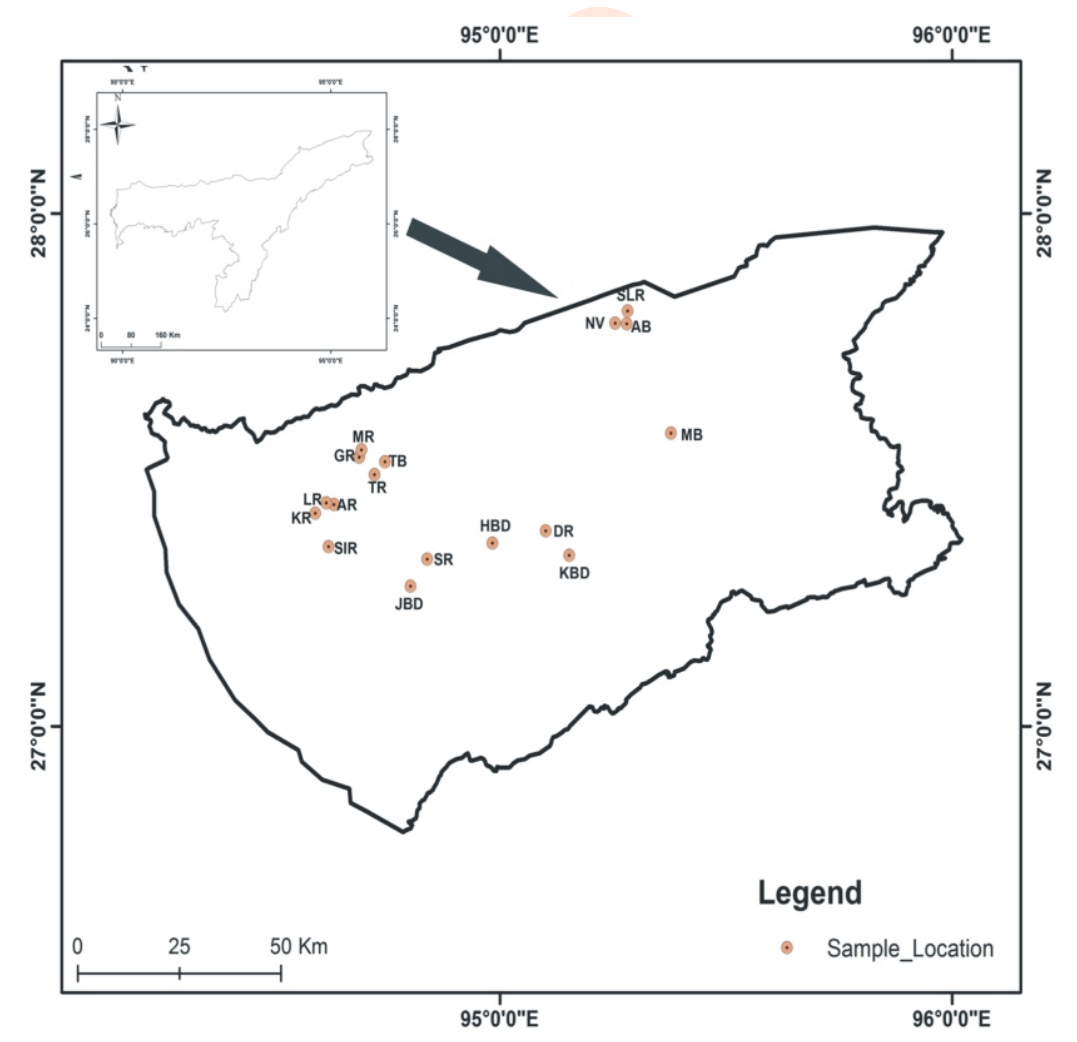

Fig.1: Map of the study area between latitude $27^{\circ} 16^{\prime} 20^{\prime \prime}-27^{\circ} 47^{\prime} 77^{\prime \prime} \mathrm{N}$ and longitude $94^{\circ} 35^{\prime} 30^{\prime \prime}-95^{\circ} 22^{\prime} 42.16^{\prime \prime} \mathrm{E}$, coloured dots are different sampling stations of the study area. 
1) covering a geographical area of approximately $3900 \mathrm{~km}^{2}$ by random sampling method. Collected specimens (Fig. 2) were acclimatized under laboratory conditions for 7 days in glass aquariums. Lamellidens spp. were identified according to Subba Rao (1989) and Ramakrishnan and Dey (2007) at the Zoological Survey of India, Kolkata.

Tissue processing for nutrient analysis: The edible parts of specimens were dissected, washed in distilled water, removed the excess water with the help of blotting paper and immediately stored at $-20^{\circ} \mathrm{C}$ deep freezer for $24 \mathrm{hrs}$ to reduce autolysis. The tissue samples were then grounded in lyophilized (Labogene Scanvac coolsafe 55-4) up to dryness and powdered samples were used to analyze the nutrient content.

Protein and amino acids analysis: One gram of sample powder was taken and crude protein content was determined by following the method of Lowry et al. (1951). Amino acid content was analyzed by following Waters AccQ. Tag Amino Acid Analysis Method.

Amino acids derivatization: In $25 \mu$ of acid hydrolyzed sample, $175 \mu \mathrm{l}$ borate buffer was added and vortexed for $10 \mathrm{sec}$. Precolumn derivatization was done by using $50 \mu \mathrm{lAccQ}$. Fluor (Waters) derivatizing agents at $56^{\circ} \mathrm{C}$ for $10 \mathrm{~min}$ and aliquots were used for amino acids analysis using Waters Breeze 2 HPLC system.

HPLC conditions: Two solvent system viz., AccQ.Tag eluent A (Waters, LOT No. 2118163161): Milli-Q type 1 water (10:90) and acetonitrile: water (60:40) were used in AccQ.Tag hydrolysate column $(3.9 \times 150 \mathrm{~mm})$ with a gradient flow. The flow rate was maintained at $1 \mathrm{ml} \mathrm{min}^{-1}$ for $65 \mathrm{~min}$. High-sensitivity detection was conducted using WT-2415 multi $\lambda$ fluorescence detector (Waters) at $250 \mathrm{~nm}$ and $395 \mathrm{~nm}$ wavelengths.

Estimation of total carbohydrate: Total carbohydrate content was estimated in acid digested tissue aliquot (neutralized) following the method of Hedge et al. (1962).

Lipid extraction and fatty acid analyses: Lipids were extracted from fresh tissue as per methods of Folch (1957) and Bligh-Dyer (1959) with modifications. To minimize auto-oxidation and photooxidation $2 \%$ Butylated hydroxytoluene (Sigma-Aldrich) in chloroform was used during lipid extraction. The chloroform extract was evaporated to dryness using $\mathrm{N}_{2}$ evaporator.

Trans-esterification and GC Conditions: The extracted lipid was trans-esterified with $14 \%$ methanolic BF3 (Sigma-Aldrich) at $80^{\circ} \mathrm{C}$ for $8 \mathrm{~min}$ and cool to room temperature followed by addition of hexane and saturated $\mathrm{NaCl}$ in 1:5 ratio, mixed well and allowed for phase separation. Finally, the hexane layer was collected over anhydrous $\mathrm{Na}_{2} \mathrm{SO}_{4}$ for gas chromatography analysis. Fatty acids methyl esters were analyzed with Clarus 680 GC (Column $60.0 \mathrm{~m}$ x 250 um) and Clarus 600C MS, PerkinEImer, USA; Liquid Autosampler. The oven temperature initially held at $60^{\circ} \mathrm{C}$ for 6 min was raised to $180^{\circ} \mathrm{C}$ at $5^{\circ} \mathrm{C} \mathrm{min}^{-1}$, and then to $280^{\circ} \mathrm{C}$ at $10^{\circ} \mathrm{C} \mathrm{min}^{-1}$ and finally held constant at $250^{\circ} \mathrm{C}$. Helium was used as the carrier gas and the injection volume was $1 \mu \mathrm{l}$. The injection port was
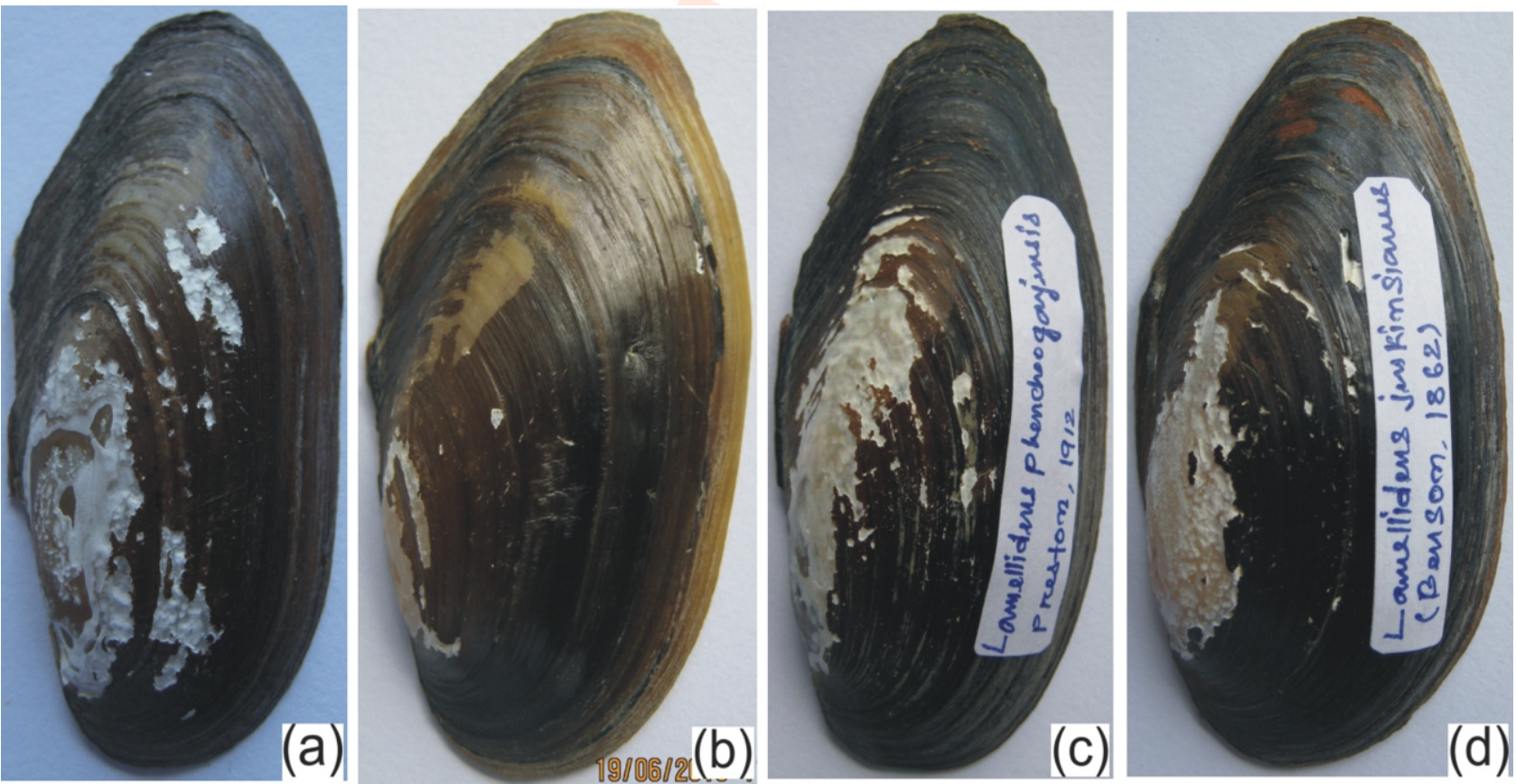

Fig. 2: Collected Lamellidens spp. from the study area: (a) L. corrianus, (b) L. marginalis, (c) L. phenchooganjensis and (d) L. jenkinsianus. 

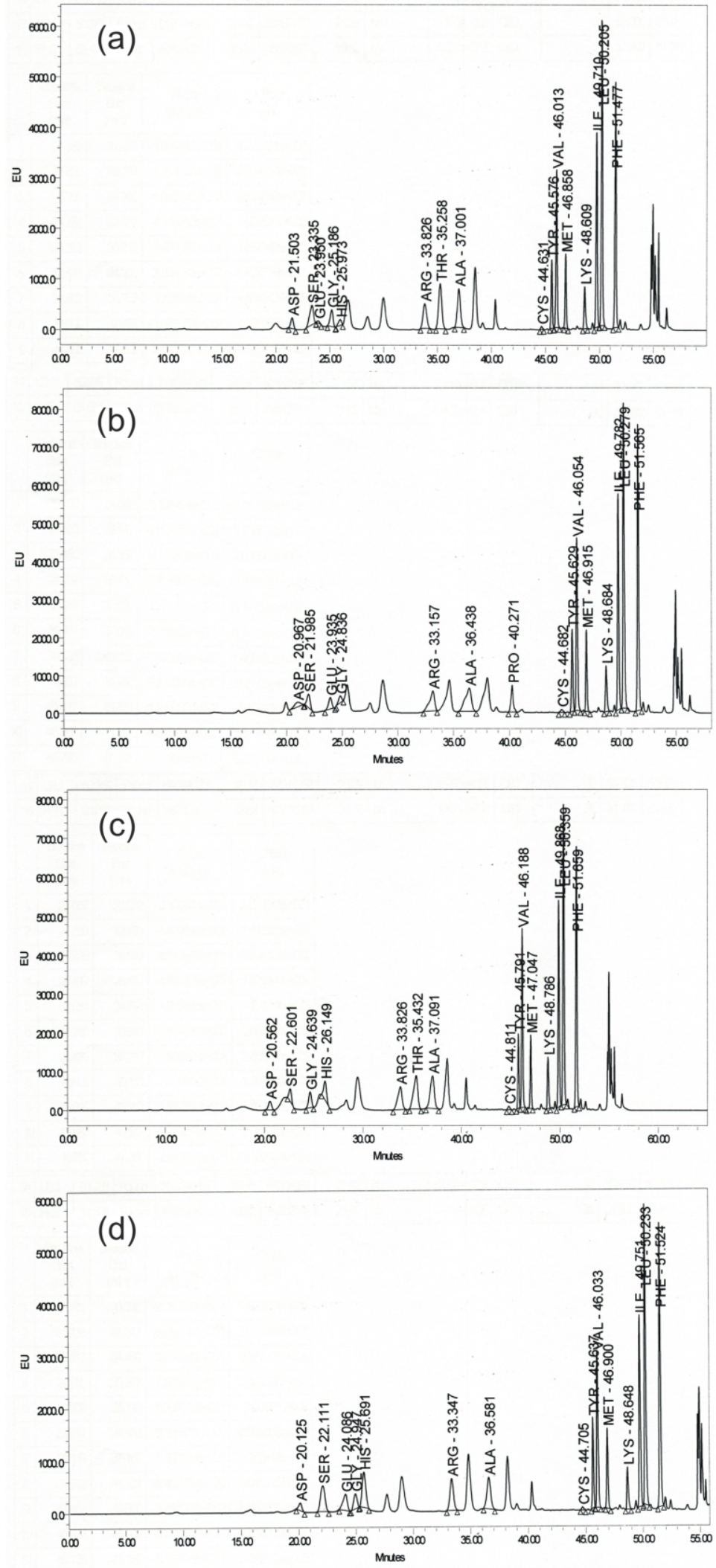

Fig. 3: HPLC chromatogram of amino acids of Lamellidens spp. (a) L. corrianus, (b) L. marginalis, (c) L. phenchooganjensis and (d) L. jenkinsianus. 


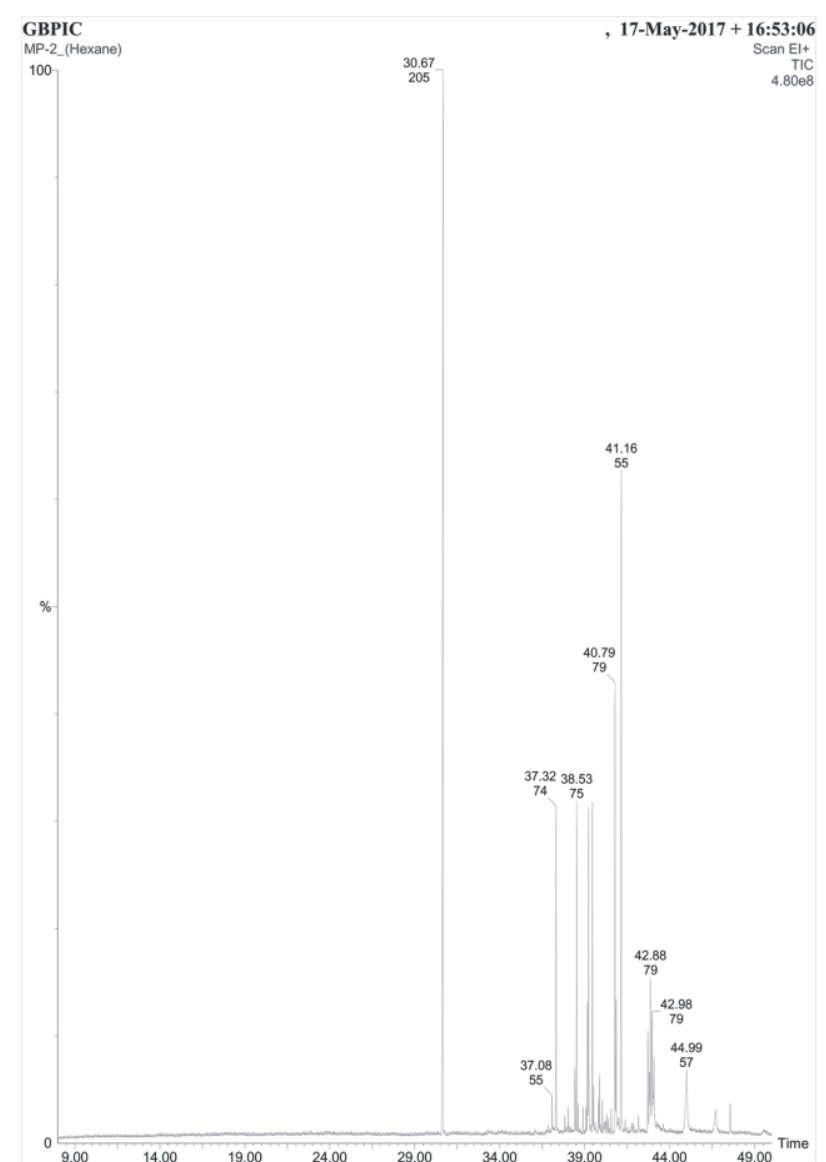

Fig. 4a : GC chromatogram fatty acid methyl esters of $L$. marginalis.

maintained at $250^{\circ} \mathrm{C}$ with transfer temperature at $200^{\circ} \mathrm{C}$ and the source temperature at $180^{\circ} \mathrm{C}$.

Mineral analysis: Mineral analysis was done by $\mathrm{HNO}_{3}$ digestion following the method of Moore (1989). Minerals were estimated with Inductively Coupled Plasma Atomic Emission Spectroscopy (ICP-AES), Model- ARCOS, Simultaneous ICP Spectrometer, SPECTROAnalytical Instruments $\mathrm{GmbH}$, Germany.

Statistical analysis: One way ANOVA was carried out to determine the significant differences if any, between the variables at $95 \%$ confidence interval using SPSS (version 20) programme.

\section{Results and Discussion}

Major nutrient contents of Lamellidens spp. are listed in Table 1. Crude protein was found to be the most dominant

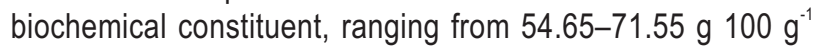
depending upon species type. Increasing demand for quality protein to meet the exploding population has led to effective and increasing exploitation of aquatic resources. For an adult,

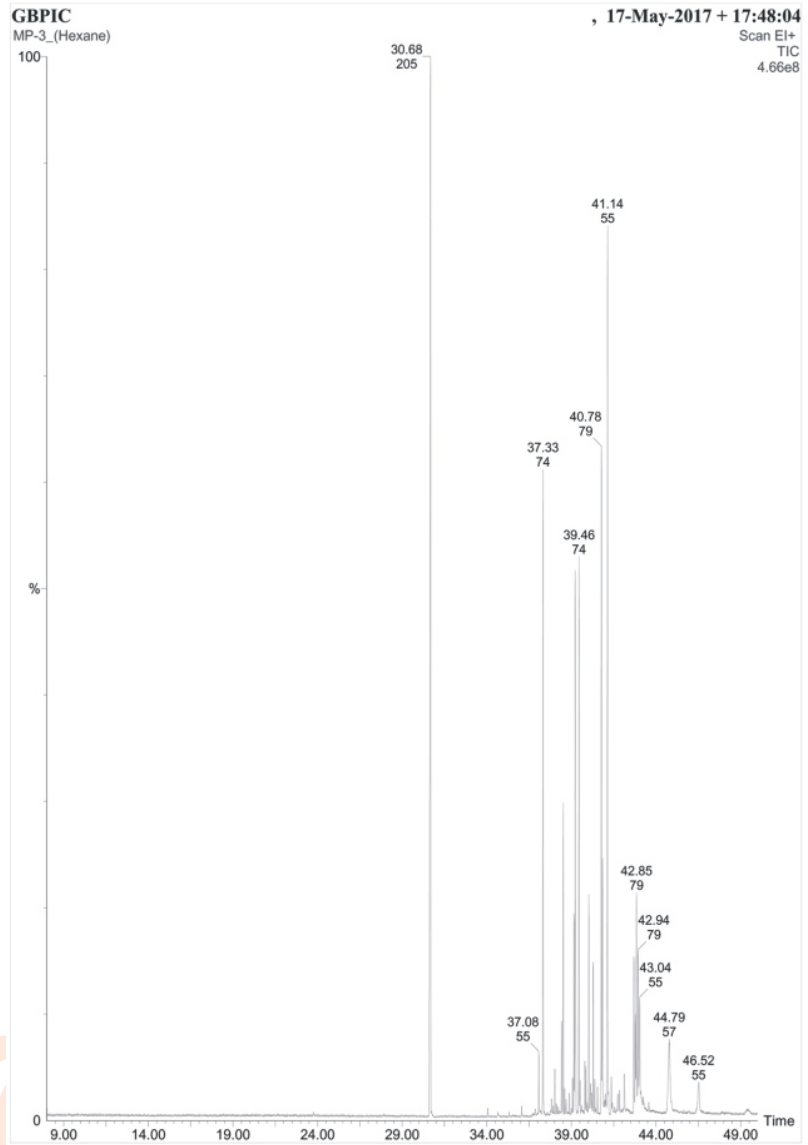

Fig. 4b: GC chromatogram of fatty acid methyl esters of $L$. phenchooganjensis.

the recommended dietary allowance (RDA) for protein is $55-60$ $\mathrm{g} \mathrm{d}^{-1}$ (NIN, 2011) and from the current study, it was observed that the Lamellidens spp. can easily fulfil the RDA value of protein (Table 1). The protein content was followed by carbohydrate content $(25-31 \%)$ whereas lipid content was found to be less than $3.5 \%$ in all four species of Lamellidens. Although glycogen is regarded as a major energy reserve in most of the bivalves (Zwaan and Zandee, 1972), protein reserve may also use as an alternative to carbohydrate, or even as primary energy source at the depletion of the later. The highest crude protein content was recorded in $L$. phenchooganjensis whereas $L$. corrianus recorded the lowest protein content among all the species studied. Thus, variation in protein content was observed among the collected species (Table 1). Similar studies indicated that variation of protein content in most bivalve is associated with the development of gonad, spawning and regression/ resting phases etc. (Lee, 1986). It is also reported that increased protein content may be a mechanism of maturation of gonads and storage of biomolecules to meet spawning requirements (Wafer et al., 1976; Nagabhushanam and Mane, 1978). 


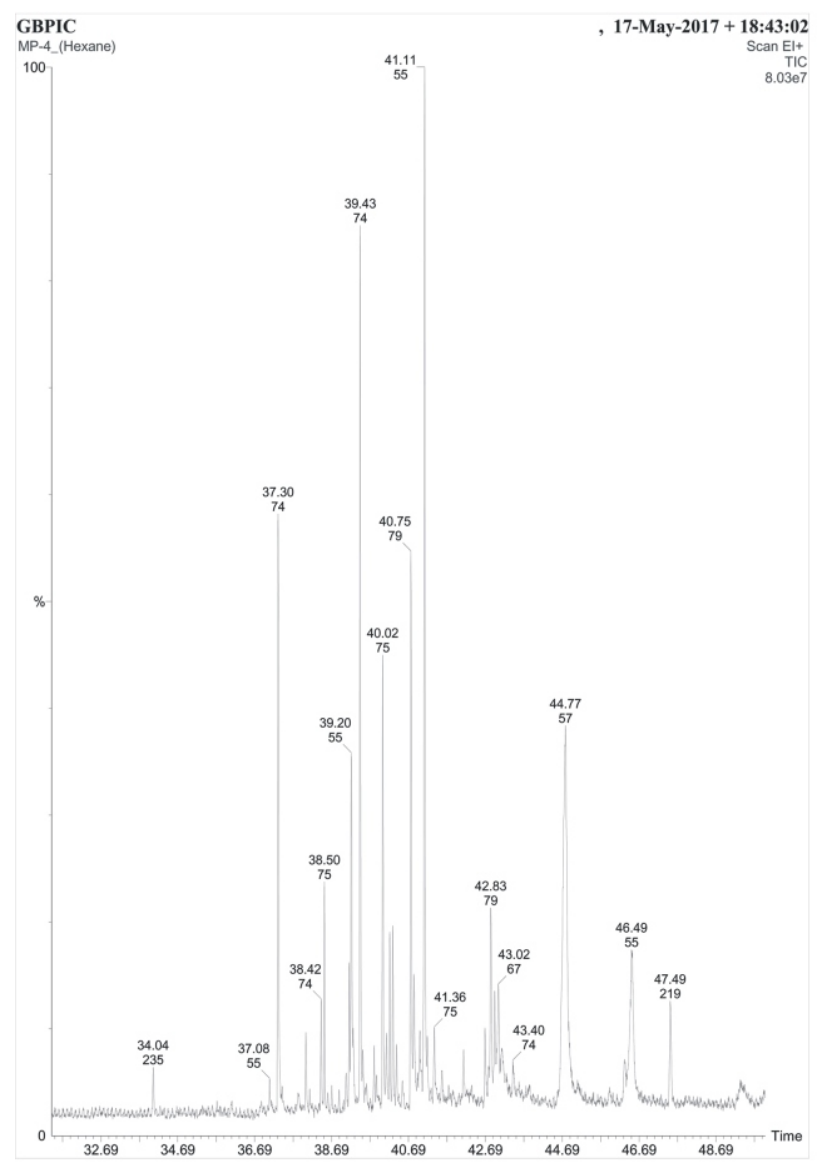

Fig. 4c: GC chromatogram fatty acid methyl esters of L. jenkinsianus.

Carbohydrates play a major role in human diet as the source of energy, but its ratio is less when compared to other organisms, especially in aquatic animals. In another study, the ratio of carbohydrate was found lesser than the other nutrients such as proteins and lipids in tissues of aquatic animals (Babu et al., 2010). In bivalves, the carbohydrate reserve may be utilized under special circumstances such as to provide precursors for the synthesis of other molecules or as a fuel molecule under unfavourable physiological condition. However, carbohydrate reserves in tissues may fluctuate widely and rapidly in response to fluctuation in habitat conditions.

The amino acid content of collected Lamellidens spp. are listed in Table 2 and HPLC chromatogram of amino acids are displayed in Fig. 3. The results show that the amount of dietary essential amino acids (DEAAs) was almost two-fold (65.84\%) as compared to dietary non-essential amino acids (34.16\%). Histidine (His), isoleucine (lle), leucine (Leu), lysine (Lys), methionine (Met), phenylalanine (Phe), threonine (Thr) and valine (Val) were the DEAAs found in Lamellidens spp. Lysine (13.43-17.55\%) was found to be highest in all four Lamellidens spp. Thr (12.98-16.62\%) and Leu (9.76-11.11\%) were recorded to be in considerable amount in the edible tissues of Lamellidens. Val (6.37-7.97\%) and lle (6.56-7.18\%) content were almost same in the tissues of all four Lamellidens spp. The other DEAAs viz., His, Met and Phy were found in less amount (Table 2). The amino acid content and its digestibility are directly related to the quality of protein. The present investigation indicates that $L$. corrianus with lower protein content (Table 1) exhibited the highest percentage of DEAAs (around 70.5\%) of total amino acids content (Table 2). As DEAAs cannot be synthesized in higher organisms, hence should be supplied in adequate quantity through diet for the proper functioning of an organism; while some of them are critically essential at certain stages of life like- during pregnancy period and infancy (Nollet, 2004). Therefore, the quantity and quality of protein are equally important for any food to be considered as nutritious. Threonine, an indispensable DEAA is useful in proper functioning of nervous system (Hyland, 2007). High content of Thr (12.98-16.62\%) in Lamellidens spp. was observed in the present study. The amount was higher as compared to other commercial animal protein source like pork, mutton and chicken (Jorfi et al., 2012); Channa spp. (Zuraini et al., 2006) and marine bivalve (Chen et al., 2012).

The present investigation indicates that the protein under study was rich in Lys, Leu, Ile, Val etc., and present in high quantity as compared to other commercial meat sources (Zuraini et al., 2006; Jorfi et al., 2012). The tissues of Lamellidens spp. are also a good source of DNEAAs (Table 2). Glutamic acid (Glu), Glycine (Gly), alanine (Ala), proline (Pro) and arginine are considered as the taste active compounds in mollusc and crab tissue (Chen and Zhang, 2007; Kani et al., 2008; Fuentes et al., 2009). These amino acids were present in a considerable amount in Lamellidens spp. (Table 2). In contrast, His, Cys and Phe were present in small amount in all four bivalve species studied. These amino acids are reported to have unpleasant taste attribute. In the present study, however, amino acids tryptophan (Trp), asparagine (Asn) and glutamine (Gln) were not detected as Trp is destroyed during acid digestion whereas Asn and GIn deaminated to aspartic acid (Asp) and Glu, respectively.

Fatty acid composition of Lamellidens spp. are listed in Table 3 and GC chromatogram of fatty acids are displayed in Fig. $4(a, b, c)$. Altogether 24 different fatty acids were detected from four Lamellidens spp. though species-specific variations in terms of quantity and quality were observed. All four Lamellidens spp. contained medium-chain fatty acids (MCFAs), long-chain saturated fatty acids (LCSFAs), monounsaturated fatty acids (MUFAs) and polyunsaturated fatty acids (PUFAs) with certain variations (Table 3, 4). These variations might be due to different physiological condition, reproductive cycle/spawning season, change of habitat parameter etc. (Foster and Hodgson, 1998; Saito et al., 1999; Brazao et al., 2003).

The PUFAs were dominated by arachidonic acid ( $\omega-6$, $16.35-19.68 \%$ of the total fatty acid count) followed by stearidonic acid ( $\omega-3,6.87-7.31 \%)$; DHA ( $\omega-3,5.14-6.74 \%)$; EPA ( $\omega-3$, $5.13-5.78 \%)$ and HPA ( $\omega-3,4.14-4.40 \%)$. Humans can 
Table 1: Major nutrient composition of Lamellidens spp.

\begin{tabular}{lllll}
\hline & \multicolumn{4}{l}{${\text { Lamellidens spp. }\left(\mathrm{g} \text { 100 } \mathrm{g}^{-1} \text { of dry tissue) }\right.}$} \\
\cline { 2 - 4 } & LC & LM & LP & LJ \\
\hline Protein & $66.6 \pm 1.08^{\mathrm{a}}$ & $69.44 \pm 2.31^{\mathrm{b}}$ & $71.55 \pm 1.63^{\mathrm{c}}$ & $54.65 \pm 3.1^{\mathrm{d}}$ \\
Carbohydrate & $30.47 \pm 1.20^{\mathrm{a}}$ & $31.25 \pm 2.57^{\mathrm{b}}$ & $25.82 \pm 0.25^{\mathrm{c}}$ & $31.67 \pm 2.3^{\mathrm{b}}$ \\
Lipid & $3.39 \pm 0.46^{\mathrm{a}}$ & $3.17 \pm 0.41^{\mathrm{b}}$ & $2.97 \pm 0.71^{\mathrm{b}}$ & $2.52 \pm 0.44^{\mathrm{d}}$ \\
\hline
\end{tabular}

${ }^{*}$ Different letters indicate the significant difference of nutrient content between the species at $p=0.05$. LC-L. corrianus, LM- L.marginalis, LP- L. phenchooganjensis, LJ- L. jenkinsianus. Values are expressed as mean of three replicates \pm S.E.

Table 2: Amino acids composition of Lamellidens spp.

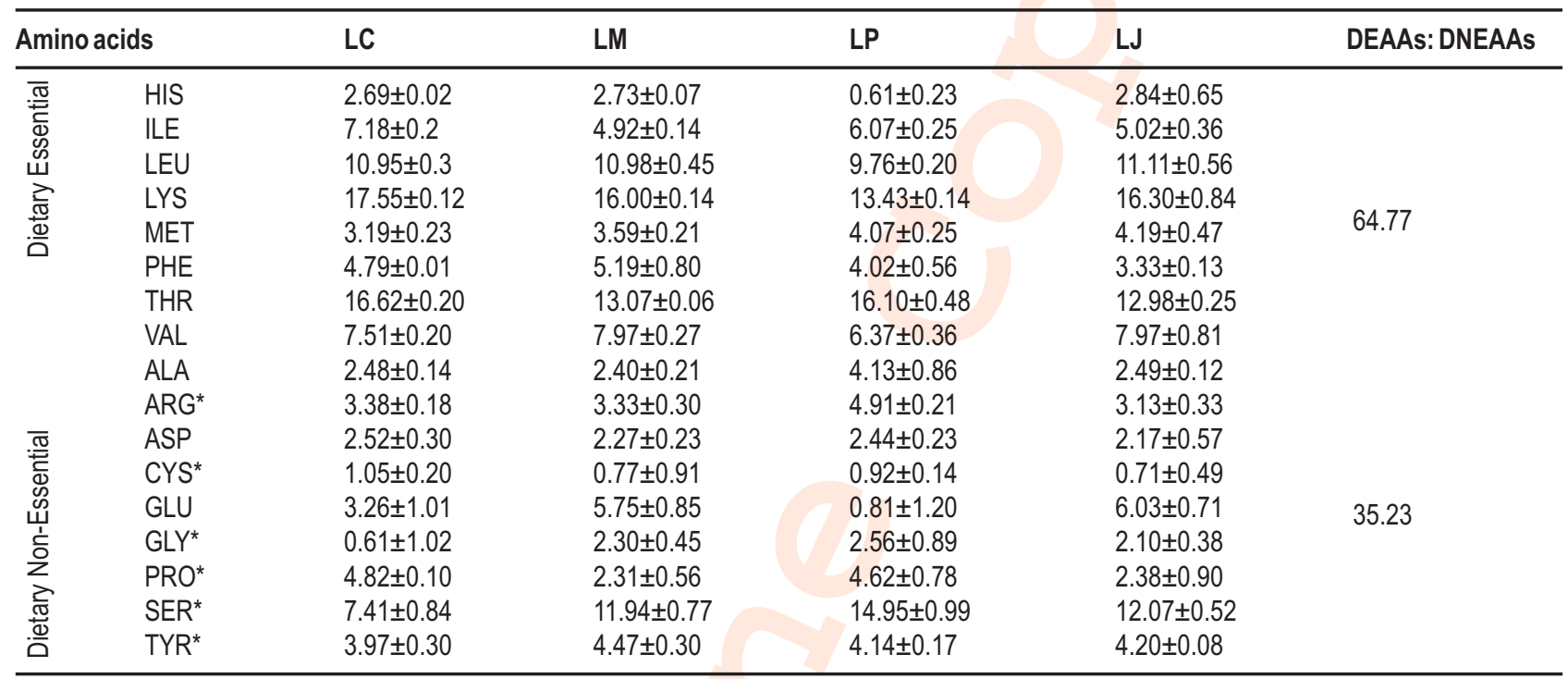

* Essential in particular physiological conditions (LC-L. corrianus, LM- L. marginalis, LP- L. phenchooganjensis, LJ- L. jenkinsianus). Values are in percentage and mean of five replicates \pm S.E.

synthesize SFAs and MUFAs besides obtaining them from the diet, however, cannot synthesize the parent PUFAs and, hence, should be incorporated through diet. PUFAs, especially $\omega-3$ and $\omega-6$ have distinct biological functions (Ratnayake and Galli, 2009; Pandalai et al., 1996; Meyer et al., 2003; Wardhana and Datau, 2011) and their absolute level ( $\omega-6: \omega-3)$ modulate physiological processes. Although a dietary ratio in the range of 5:1 to 10:1 has been recommended (FAO, 1994), recent studies suggest that increase in the absolute levels of $\omega-3$ PUFAs is more suitable (Harris et al., 2008; Candela et al., 2011; Simopoulos, 2016). In the present investigation, the amount of $\sum \omega-3$ is higher than that of $\sum \omega-6$ making the Lamellidens spp. a good source of $\omega-3$ fatty acids. The result is significant due to the presence of a good amount of stearidonic acid. Besides its role in increasing red blood cells, stearidonic acid has the ability to convert EPA and DHA(17-41\%) more efficiently overALA(Walker et al., 2013).

Among the MUFAs, gadoleic acid (C20:1, $\omega-11)$ and cetoleic acid (C22:1, $\omega$-11) were dominant fatty acids accounting for $20.12-21.14 \%$ and $1.64-4.11 \%$, respectively. These two fatty acids are long-chain MUFAs (LCMUFAs) and their supplement in human diet will favourably alter the lipoprotein profile regarding cardiovascular disease risk (Sorokin et al., 2019) and improve the capacity to synthesize health-promoting $\omega-3$ fatty acids EPA and DHA in human and fish models (Østbye et al., 2019). Myristoleic acid (C14:1, $\omega-5)$ accounts for $1.14-1.39 \%$, a $\omega-5$ LCMUFA is uncommon in nature and its cytotoxic and effective apoptosis inducer activity can be used for the treatment of prostate cancer and necrosis of human prostatic LNCaP cells (Iguchi et al., 2001). During analysis, two MCFAs were also found in the tissues of Lamellidens spp. viz., isodecanoic acid (C10:0) and undecanoic acid (C11:0) that accounted 4.58-7.14\% and $5.14-14.51 \%$ of the total fatty acids, respectively. Due to short chain length, MCFAs are more rapidly broken down and absorbed into the body compared to LCSFAs.

This property makes them a quick energy source and less likely to be stored as fat. Researchers suggest that MCFAs in human diet may also reduce the body weight and have a suppressing effect on the body fat accumulation in individuals 
Table 3: List of fatty acids/ fatty acid methyl esters of Lamellidens spp. after GC/GC-MS analysis (+ and-indicate the presence or absence of fatty acids)

\begin{tabular}{|c|c|c|c|c|c|c|}
\hline \multicolumn{3}{|l|}{ Fatty acids/ Fatty acid methyl esters } & \multicolumn{4}{|c|}{ Lamellidens spp. } \\
\hline IUPAC Name & Common name & C:D & LC & LM & LP & LJ \\
\hline 8-methylnonaoic acid & Isodecanoic acid & $10: 0$ & - & - & + & + \\
\hline Undecanoic acid & Undecanoic acid & $11: 0$ & - & - & - & + \\
\hline 12-methyltridecanoic acid & Isomyristic acid (branched chain ) & $14: 0$ & - & - & - & + \\
\hline Pentadecanoic acid & Pentadecanoic acid & $15: 0$ & - & + & + & - \\
\hline Hexadecanoic acid & Palmitic acid & $16: 0$ & + & + & + & - \\
\hline Heptadecanoic acid & Margaric acid & $17: 0$ & + & + & - & - \\
\hline 15 - methyl Hexadecanoic acid & $\begin{array}{l}15 \text { - methyl Hexadecanoic acid } \\
\text { (branched fatty acid) }\end{array}$ & $17: 0$ & + & - & + & - \\
\hline 16-methyl heptadecanoic acid & Isostearic acid & $18: 0$ & + & + & + & + \\
\hline 9,10-methylene octadecanoic acid & Dihydrosterculic acid & $19: 0$ & + & - & + & - \\
\hline Heptacosanoic acid & Carboceric acid & $27: 0$ & - & - & + & + \\
\hline (Z) - tetradec-9-enoic acid & Myristoleic acid & $14: 1(\omega-5)$ & + & - & + & + \\
\hline Hexadec - 11 - enoic acid & Palmitoleic acid & $16: 1$ & - & + & - & - \\
\hline Octadec-13-enoic acid & 13-octadecenoic acid & $18: 1$ & - & + & + & + \\
\hline (9Z)-9-Icosenoic acid & Gadoleic acid & $20: 1(\omega-11)$ & + & + & - & + \\
\hline icosa - 5 - enoic acid & 5 - Eicosenoic acid & $20: 1$ & - & - & + & - \\
\hline docos- 11- enoic & Cetoleic acid & $22: 1(\omega-11)$ & + & + & + & + \\
\hline Octadeca - 9, 10 - dienoic acid & Conjugated Linoleic acid (CLA) & $18: 2$ & + & + & - & + \\
\hline $\begin{array}{l}(11 Z, 14 Z) \text { - octadeca - } \\
11,14 \text { - dienoic acid }\end{array}$ & Octadecadienoic acid (CLA) & $18: 2$ & - & - & + & - \\
\hline octadeca - 12, 13- dienoic acid & Octadecadienoic acid (CLA) & $18: 2$ & + & - & + & + \\
\hline 6,9,12,15-octadecatetraenoic acid & Stearidonic acid & $18: 4(\omega-3)$ & - & - & - & + \\
\hline $\begin{array}{l}(5 Z, 8 Z, 11 Z, 14 Z, 17 Z) \text { - icosa - } 5 \\
8,11,14,17 \text { - pentaenoic acid }\end{array}$ & EPA & $20: 5(\omega-3)$ & + & + & + & + \\
\hline $\begin{array}{l}(6 Z, 9 Z, 12 Z, 15 Z, 18 Z)-\text { heneicosa } \\
-6,9,12,15,18-\text { pentanoic acid }\end{array}$ & HPA & $21: 5(\omega-3)$ & - & + & + & + \\
\hline $\begin{array}{l}(4 Z, 7 Z, 13 Z, 16 Z, 19 Z)-\text { docosa }-4,7 \\
13,16,19 \text { - hexaenoic acid }\end{array}$ & DHA or Cervonic acid & $21: 6(\omega-3)$ & + & + & + & + \\
\hline icosa $-5,8,11,14$ - tetraenoic acid & Arachidonic acid & $20: 4(\omega-6)$ & + & + & + & + \\
\hline
\end{tabular}

* C:D - Carbon Number: Double bond; LC-L. corrianus, LM- L. marginalis, LP- L. phenchooganjensis, LJ- L. jenkinsianus

Table 4: Fatty acids composition of Lamellidens spp.

\begin{tabular}{lllll}
\hline Fatty acids & L. corrianus & L. marginalis & L. phenchooganjensis & L. jenkinsianus \\
\hline$\sum$ PUFA & $38.80 \pm 1.04$ & $36.59 \pm 0.13$ & $39.54 \pm 0.93$ & $32.06 \pm 0.09$ \\
$\sum$ MUFA & $33.41 \pm 0.77$ & $45.09 \pm 0.40$ & $24.40 \pm 0.08$ & $28.93 \pm 0.25$ \\
$\sum$ LCSFA & $14.19 \pm 0.82$ & $18.21 \pm 0.62$ & $36.04 \pm 0.85$ & $22.61 \pm 0.54$ \\
$\sum$ MCFA & $13.58 \pm 0.93$ & ND & ND & $16.38 \pm 0.45$ \\
\hline
\end{tabular}

${ }^{*} \mathrm{ND}$ - not detected. Values are expressed percentage and are mean of three replicates $\pm S . E$.

(Tsuji et al., 2001; Takeuchi et al., 2008). The content of selected minerals in the tissues of Lamellidens spp. is listed in Table 5. The results showed that Lamellidens spp. is a good source of macro and trace elements for humans. However, variation in mineral content is observed in different species where macro element like Ca (1339.65 mg kg $)$, Mg (19.43 mg kg ${ }^{-1}$ ) and trace element like Fe $\left(251.48 \mathrm{mg} \mathrm{kg}^{-1}\right)$ was found highest in $L$. marginalis. The highest $\mathrm{Cu}$ content was found in the tissues of $L$. jenkinsianus, while the highest amount of $\mathrm{Zn}\left(8.95 \mathrm{mg} \mathrm{kg}^{-1}\right)$ was recorded in $L$. phenchooganjensis tissue. $L$. corrianus contained the least amount of minerals compared to other Lamellidens spp. During the present study heavy metals such as $\mathrm{As}, \mathrm{Cd}, \mathrm{Hg}$ and $\mathrm{Pb}$ were not detected in the tissues of Lamellidens spp.

Human beings require a wide range of minerals to lead a healthy and active life. Therefore, the diet should be selected 
Table 5: Mineral compositions of Lamellidens spp.

\begin{tabular}{lllll}
\hline $\begin{array}{l}\text { Minerals } \\
\left.(\mathbf{m g ~ K g})^{-1}\right)\end{array}$ & L C & L M & L P & L J \\
\cline { 2 - 5 } & $845.35 \pm 2.14^{\mathrm{a}}$ & $1339.65 \pm 3.10^{\mathrm{b}}$ & $1049.63 \pm 1.93^{\mathrm{c}}$ & $1136.57 \pm 2.02^{\mathrm{d}}$ \\
$\mathrm{Ca}$ & $15.10 \pm 1.07^{\mathrm{a}}$ & $19.43 \pm 1.33^{\mathrm{b}}$ & $18.70 \pm 0.97^{\mathrm{c}}$ & $19.38 \pm 1.88^{\mathrm{d}}$ \\
$\mathrm{Mg}$ & $15.98 \pm 2.01^{\mathrm{a}}$ & $251.48 \pm 1.77^{\mathrm{b}}$ & $164.98 \pm 0.17^{\mathrm{c}}$ & $28.55 \pm 3.01^{\mathrm{d}}$ \\
$\mathrm{Fe}$ & $0.11 \pm 0.17^{\mathrm{a}}$ & $0.13 \pm 0.09^{\mathrm{b}}$ & $0.15 \pm 0.12^{\mathrm{c}}$ & $0.47 \pm 0.08^{\mathrm{d}}$ \\
$\mathrm{Cu}$ & $6.17 \pm 1.01^{\mathrm{a}}$ & $14.84 \pm 2.02^{\mathrm{b}}$ & $15.12 \pm 1.77^{\mathrm{c}}$ & $8.95 \pm 0.78^{\mathrm{d}}$ \\
$\mathrm{Zn}$ & $\mathrm{ND}$ & $\mathrm{ND}$ & $\mathrm{ND}$ & $\mathrm{ND}$ \\
$\mathrm{Se}$ & $\mathrm{ND}$ & $\mathrm{ND}$ & $\mathrm{ND}$ \\
$\mathrm{Cd}$ & $\mathrm{ND}$ & $\mathrm{ND}$ & $\mathrm{ND}$ \\
$\mathrm{Pb}$ & $\mathrm{ND}$ & $\mathrm{ND}$ & $\mathrm{ND}$ \\
$\mathrm{Hg}$ & $\mathrm{ND}$ & $\mathrm{ND}$ & $\mathrm{ND}$ \\
$\mathrm{As}$ & $\mathrm{ND}$ & $\mathrm{ND}$ & $\mathrm{n}$ & \\
\hline
\end{tabular}

*Different letters indicate the significant difference of mineral content between the species at $p=0.05$; ND - Not detected. Values are expressed as mean of three replicates \pm S.E.

Table 6: Recommended Dietary Allowance (RDA) of minerals for Indians and selected mineral contained in Lamellidens spp. per 100g of tissue

\begin{tabular}{|c|c|c|c|c|c|c|c|c|c|}
\hline Group & Age & $\mathrm{Ca}\left(\mathrm{mg} \mathrm{d}^{-1}\right)$ & 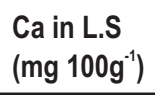 & $\mathrm{Fe}\left(\mathrm{mg} \mathrm{d}^{-1}\right)$ & 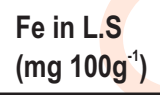 & $M g\left(\mathrm{mg} \mathrm{d}^{-1}\right)$ & 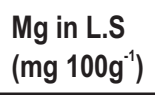 & $\mathrm{Zn}\left(\mathrm{mg} \mathrm{d}^{-1}\right)$ & $\begin{array}{l}\mathrm{Zn} \text { in L.S } \\
\left(\mathrm{mg} 100 \mathrm{~g}^{-1}\right)\end{array}$ \\
\hline \multirow[t]{3}{*}{ Man } & $\begin{array}{l}\text { Matured, } \\
\text { Normal }\end{array}$ & 600 & & 17 & & 340 & & 12 & \\
\hline & $\begin{array}{l}\text { Matured, } \\
\text { Normal }\end{array}$ & 600 & & 21 & & & & 10 & \\
\hline & Pregnant & & & 35 & & & & & \\
\hline \multirow[t]{2}{*}{ Woman } & $\begin{array}{l}\text { Lactation } \\
0-6 \text { months }\end{array}$ & 1200 & & 21 & & 310 & & & \\
\hline & $\begin{array}{l}\text { Lactation } \\
6-12 \text { months }\end{array}$ & & & & & & & 12 & \\
\hline \multirow{3}{*}{ Infants } & $0-6$ months & & 117.52 & & 11.52 & 30 & 1.94 & - & 1.50 \\
\hline & $6-12$ months & 500 & & 5 & & 45 & & - & \\
\hline & $1-3$ years & & & 9 & & 50 & & 5 & \\
\hline \multirow[t]{2}{*}{ Children } & 4-6 years & 600 & & 13 & & 70 & & 7 & \\
\hline & $7-9$ years & & & 16 & & 100 & & 8 & \\
\hline Boys & 10-17 years & 800 & & $21-32$ & & $120-195$ & & $9-12$ & \\
\hline Girls & $10-17$ years & 800 & & $27-28$ & & $160-235$ & & $9-12$ & \\
\hline
\end{tabular}

*L.S - average mineral content in Lamellidens spp.

Table 7: RDAscore (\%) of selected minerals per 100g tissue of Lamellidens spp. and their nutrient food source type

\begin{tabular}{|c|c|c|c|c|}
\hline \multirow{2}{*}{ Minerals } & \multicolumn{4}{|c|}{ Nutrient Source Type of FDA Standards } \\
\hline & $\begin{array}{l}\text { Excellent } \\
\text { (25\% RDA or more) }\end{array}$ & $\begin{array}{l}\text { Good } \\
\text { (Less than 25\% RDA) }\end{array}$ & $\begin{array}{l}\text { Average } \\
\text { (Less than 10\% RDA) }\end{array}$ & $\begin{array}{l}\text { Poor } \\
\text { ( Less than } 5 \% \text { RDA) }\end{array}$ \\
\hline $\begin{array}{l}\mathrm{Ca} \\
\mathrm{Fe}\end{array}$ & C10/ & $16.78 \%$ RDA & & \\
\hline $\mathrm{Mg}$ & . & & & $0.33 \% \mathrm{RDA}$ \\
\hline $\mathrm{Zn}$ & & $10 \% \mathrm{RDA}$ & & \\
\hline $\mathrm{Cu}$ & $25 \% \mathrm{RDA}$ & & & \\
\hline
\end{tabular}

judiciously to gain all the essential nutrients in proper proportions for different physiological activities. However, the requirement of each nutrient depends on the age, gender, body weight and physiological state of an individual. The recommended dietary allowance of minerals for different age group of the Indian population and the minerals contained in Lamellidens spp. per 
$100 \mathrm{~g}$ dry tissue is listed in Table 6 (NIN, 2011). The result may be promising as all four species of Lamellidens were good sources of minerals viz., $\mathrm{Ca}, \mathrm{Fe}, \mathrm{Zn}$ and $\mathrm{Cu}$, except for Mg. Lamellidens spp. are found to be an excellent source of $\mathrm{Fe}$ and $\mathrm{Cu}$ which fulfils more than $25 \%$ RDA per $100 \mathrm{~g}$ of raw tissue, followed by $\mathrm{Ca}$ and Zn which fulfils $16.78 \%$ and $10 \%$ RDA, respectively (Table 7).

In conclusion, the present study is a validation of the fact that freshwater mussel Lamellidens spp. are a better source of proteins, dietary essential amino acids, fatty acids as well as macro and trace minerals for human nutrition as compared to marine bivalves and other commercial meat. The outcome of the present study is first-hand information on the nutritive value of Lamellidens spp. from the upper Brahmaputra basin of Assam. Therefore, Lamellidens spp. may be considered as an excellent meat for human consumption. A sustainable approach could be made by developing a culture protocol (in-vivo or in-vitro) to exploit aquatic bio-resource as a rich supplement of human diet especially for the rural populace in the region.

\section{Acknowledgments}

Authors are thankful to IIT Bombay, IIT Guwahati Biotech. Park; ZSI, Kolkata for technical support, DST INSPIRE Programme and DST-SERB for financial support and also to DSTFIST, Department of Life Sciences, Dibrugarh University for providing necessary facilities for carrying out the study.

\section{References}

Ab Lah, R., J. Smith, D. Savins, A. Dowell, D. Bucher and K. Benkendorff: Investigation of nutritional properties of three species of marine turban snails for human consumption. Food Sci. Nutr., 5, 14-30 (2016).

Babu, A., K. Kesavan, D. Annadurai and S. Rajagopal: Bursa spinosa - A mesogastropod fit for human consumption. Adv. J. Food Sci. Tech., 2,79-83(2010)

Bligh, E.G. and W.J. Dyer: A rapid method of total lipid extraction and purification. Can. J. Biochem. Phys., 37, 911-917 (1959).

Brazao, S., S. Morais, D. Boaventura, P. Re, L. Narciso and S.J. Hawkins: Spatial and temporal variation of the fatty acid composition of Patella spp. (Gastropoda: Prosobranchia) soft bodies and gonads. Comp. Biochem. Physiol. B. Biochem. Mol. Biol., 136, 425-441 (2003).

Budha, P.B., N.A. Aravind and B.A. Daniel: The status and distribution of freshwater molluscs of the eastern Himalaya. The status and distribution of freshwater biodiversity in the Eastern Himalaya (Eds.: D.J.Allen, S. Molur and B.A. Daniel). IUCN, pp. 42-53 (2010).

Candela, C.G., L.B. López and V.L. Kohen: Importance of a balanced omega 6/omega 3 ratio for the maintenance of health. Nutritional recommendations. Nutr. Hosp., 26, 323-329 (2011).

Chen, D.W. and M. Zhang: Non-volatile taste active compounds in the meat of Chinese mitten crab (Eriocheir sinensis). Food Chem., 104, 1200-1205 (2007)

Chen, D.W., J. Su, X.L. Liu, D.M. Yan, Y. Lin, W.M. Jiang and X.H. Chen: Amino acid profiles of bivalve mollusks from Beibu Gulf, China. J. Aquat. Food Prod. Technol., 21, 369-379 (2012).

De Zwaan, A. and D.I. Zandee: Body distribution and seasonal changes in the glycogen content of the common sea mussel Mytilus edulis.
Comp. Biochem. Physiol., 43A, 53-58 (1972).

Dridi, S., M.S. Romdhane and M.H. Elcafsi: Seasonal variation in weight and biochemical composition of the Pacific oyster, Crassostrea gigas in relation to the gametogenic cycle and environmental conditions of the Bizert lagoon, Tunisia. Aquaculture, 263, 238-248 (2007).

Elder, J.F. and J.J. Collins: Freshwater molluscs as indicators of bioavailability and toxicity of metals in surface-water systems. In: Reviews of Environmental Contamination and Toxicology, Springer, New York, pp. 37-79 (1991).

FAO/WHO: Fats and oils in human nutrition. Report of a Joint Expert Consultation. Food and Agriculture Organization of the United Nations, Rome, Italy, p. 168 (1994).

Folch, J., M. Lees and G.H.S.A. Stanley: A simple method for total lipid extraction and purification. J. Biol. Chem., 226, 497-509 (1957).

Food \& Drugs Administration, U.S. Department of Health \& Human Services (2015). https://www.fda.gov/Food/default.htm

Foster, G.G. and A.N. Hodgson: Consumption and apparent dry matter digestibility of six intertidal macroalgae by Turbo sarmaticus (Mollusca: Vetigastropoda: Turbinidae). Aquaculture, 167, 211227 (1998)

Fuentes, A., T. Fernández-Segovia, I. Escriche and J.A. Serra: Comparison of physico-chemical parameters and composition of mussels (Mytilus galloprovincialis Lmk.) from different Spanish origins. Food Chem., 112, 295-302 (2009).

Gutierrez, J.L., C.G. Jones, D.L. Strayer and O.O. Iribarne: Mollusks as ecosystem engineers: The role of shell production in aquatic habitats. Oikos, 101, 79-90 (2003).

Harris, W.S., M. Miller, A.P. Tighe, M.H. Davidson and E.J. Schaefer: Omega- 3 fatty acids and coronary heart disease risk: Clinical and mechanistic perspectives. Atherosclerosis, 197, 12-24 (2008).

Hedge, J.E., B.T. Hofreiter and R.L. Whistler: Carbohydrate Chemistry. Academic Press, New York, p.17 (1962).

Hyland, K.: Inherited disorders affecting dopamine and serotonin: Critical neurotransmitters derived from aromatic amino acids. J. Nutr., $137,1568-1572$ (2007).

Iguchi, K., N. Okumura, S. Usui, H. Sajiki, K. Hirota and K. Hirano: Myristoleic acid, a cytotoxic component in the extract from Serenoa repens, induces apoptosis and necrosis in human prostatic LNCaP cells. The Prostate, 47, 59-65 (2001).

Jorfi, R., S. Mustafa, Y.B.C. Man, D.B.M. Hashim, A.Q. Sazili, A.S. Farjam and P. Kashiani: Differentiation of pork from beef, chicken, mutton and chevon according to their primary amino acids content for halal authentication. Afr. J. Biotechnol., 11, 8160-8166 (2012).

Kani, Y., N. Yoshikawa, S. Okada and H. Abe: Taste-active components in the mantle muscle of the oval squid Sepioteuthis lessoniana and their effects on squid taste. Food Res. Int., 41, 371-379 (2008).

Lee, S.Y.: Growth and reproduction of the green mussel Perna viridis (L.) (Bivalvia: Mytiliacea) in contrasting environments in Hong Kong. Asian Marine Biol., 3, 111-127 (1986).

Linehan, L.G., T.P. O'Connor and G. Burnell: Seasonal variation in the chemical composition and fatty acid profile of Pacific oysters (Crassostrea gigas). Food Chem., 64, 211-214 (1999).

Lowry, O.H., N.J. Rosebrough, A.L. Farr and R.J. Randall: Protein measurement with the Folin phenol reagent. J. Biol. Chem., 193, 265-275 (1951).

Lydeard, C., R.H. Cowie, W.F. Ponder, A.E. Bogan, P. Bouchet, S.A. Clark, K.S. Cummings, T.J. Frest, O. Gargominy, D.G. Herbert, R. Hershler, K.E. Perez, B. Roth, M. Seddon, E.E. Strong and F.G. Thompson: The global decline of nonmarine mollusks. BioScience, 54, 321-330 (2004).

Madhyastha, A., P.B. Budha and B.A. Daniel: Lamellidens marginalis. The IUCN Red List of Threatened Species 2010: e. T166731 
A6270763 (2010).

Maltchik, L., C. Stenert, C.B. Kotzian and D. Pereira: Responses of freshwater molluscs to environmental factors in Southern Brazil wetlands. Braz. J. Biol., 70, 473-482 (2010).

Meyer, B.J., N.J. Mann, J.L. Lewis, G.C. Milligan, A.J. Sinclair and P.R. Howe: Dietary intakes and food sources of omega- 6 and omega- 3 polyunsaturated fatty acids. Lipids, 38, 391-398 (2003).

Moore, G.L.: Introduction to inductively coupled plasma atomic emission spectrometry. In: Analytical Spectroscopy Library, Elsevier, Amsterdam, Vol. 3, p. 340 (1989).

Nagabhushanam, R. and U.H. Mane: Seasonal variation in the biochemical composition of Mytilus viridis at Ratnagiri, on west coast of India. Hydrobiologia, 57, 69-72 (1978).

NIN (National Institute of Nutrition): Dietary Guidelines for Indians- A Manual, ICMR, Hyderabad (2011). http://ninindia. org/Dietary GuidelinesforNINwebsite.pdf

Nollet, L.M.L.: Handbook of Food Analysis: Methods and Instruments in Applied Food Analysis, Vol. 138, CRC Press (2004).

Østbye, T.K.K., G.M. Berge, A. Nilsson, O.H. Romarheim, M. Bou and B. Ruyter: The long-chain monounsaturated cetoleic acid improves the efficiency of the $n-3$ fatty acid metabolic pathway in Atlantic salmon and human HepG2 cells. Brit. J. Nutr., 122, 755-768 (2019).

Pandalai, P.K., M.J. Pilat, K. Yamazaki, H. Naik and K.J. Pienta: The effects of omega- 3 and omega- 6 fatty acids on in-vitro prostate cancer growth. Anticancer Res., 16, 815-820 (1996).

Ramakrishnan and A. Dey: Handbook on Indian Freshwater Molluscs. Zoological Survey of India, Kolkata (2007).

Ratnayake, W.M.N. and C. Galli: Fat and fatty acid terminology, methods of analysis and fat digestion and metabolism: A background review paper. Ann. Nutr. Metab., 55, 8-43 (2009).

Saito, H., R. Yamashiro, C. Alasalvar and T. Konno: Influence of diet on fatty acids of three subtropical fish, subfamily Caesioninae (Caesiodia gramma and C. tile) and family Siganidae (Siganus canaliculatus). Lipids, 34, 1073-1082 (1999).

Simopoulos, A. P.: An increase in the omega-6/omega-3 fatty acid ratio increases the risk for obesity. Nutrients, 8, 1-17 (2016).

Sorokin, A.V., Z.H. Yang, C. Ling, K. Donkor, E. Staller, M.J. Amar and A.T. Remaley: Effects of fish oil enriched in omega- 11 fatty acid on lipoprotein metabolism in healthy adults. Arte. Throm. Vas. Biol., 39, A332-A332 (2019).

Subba Rao, N.V.: Handbook of Freshwater Molluscs of India. Zoological Survey of India, Kolkata (1989).

Suna, S. and Ö. U. Çopur: A New Approach: Replacement and alternative foods for food industry. In: Alternative and Replacement Foods (Eds.: A. M. Holban and A. M. Grumezescu). Academic Press, Elsevier Inc., pp. 1-30 (2018).

Takeuchi, H., S. Sekine, K. Kojima and T. Aoyama: The application of medium-chain fatty acids: Edible oil with a suppressing effect on body fat accumulation. Asia Pac. J. Clin. Nutr., 7, 320-323 (2008).

Tsuji, H., M. Kasai, H. Takeuchi, M. Nakamura, M. Okazaki and K. Kondo: Dietary medium-chain triacylglycerols suppress accumulation of body fat in a double-blind, controlled trial in healthy men and women. J. Nutr., 131, 2853-2859 (2001).

Wafer, M.V.M., S. Vijayaraghawan and L. Krishnakumari: Seasonal changes in the nutritive values of the Green Mussel Mytilus viridis (L.). Indian J. Marine Sci., 5, 252-254 (1976).

Walker, C.G., S.A. Jebb and P.C. Calder: Stearidonic acid as a supplemental source of $\omega-3$ polyunsaturated fatty acids to enhance status for improved human health. Nutrition, 29, 363-369 (2013).

Wardhana, E.E.S. and E.A. Datau: The role of omega-3 fatty acids contained in olive oil on chronic inflammation. Inflammation, 43, 138-143 (2011).

Zuraini, A., M.N. Somchit, M.H. Solihah, Y.M. Goh, A.K. Arifah, M.S. Zakaria and A.M. Jais: Fatty acid and amino acid composition of three local Malaysian Channa spp. fish. Food Chem., 97, 674-678 (2006). 